\title{
Implications of Budgeting and Budgetary Control on Construction Project Delivery in Nigeria
}

\author{
Nwokenkwo, Ben Chinedum \\ Department of Estate Management and Valuation, Federal Polytechnic, Bida. Niger State. Nigeria
}

\begin{abstract}
The growing need for construction of all types coupled with a tight monetary supply has provided the construction industry with a big challenge to work within budget and invariably to cut cost. Clients expect a high level of transparency in project cost accounting and good value for their investment. This can only be achieved through proper budgeting and effective budgetary control of the building processes from inception to completion. This is the kernel of this paper. Having identified the target groups (clients, consultants and contractors) seventy respondent, purposively selected were given structured questionnaires, selected using stratified random sampling technique, a type of probability sampling in order to give everyone that falls into any of these identified target group equal and independent chance of being included in the sample. From the analyzed responses, it was observed that non application of relevant budgetary control has adverse implications like time and cost overrun on projects. It is therefore recommended that an effective application of budgeting and budgetary control will make way for successful completion and delivery of a construction project
\end{abstract}

Keywords: Budgeting, Project Delivery, Construction client, Budgetary Control.

DOI: $10.7176 / \mathrm{CER} / 11-8-08$

Publication date:September $30^{\text {th }} 2019$

\subsection{Introduction}

The construction industry is an important sector of the economy which makes good contribution to the economy and growth of the nation. It is the industry that harnesses men, materials, machines, money and method toward the realization of the project that is meant to satisfy the shelter and infrastructure needs of industries in the society. The industry is basically unique in the sense that it adopts a project approach; it has a definite start within a fixed cost and time. The final product of construction industry is often large and expensive and is required over a wide geographical area. Thus the growing need for construction of all types coupled with a tight monetary supply has provided the construction industry with a big challenge to cut cost. According to Mendelson and Greenfield (1996), the remaining part of the $20^{\text {th }}$ century would involve corporations, institutions and government in a race to survive. The attendant dwindling economic fortune of nations economies around the world have geared up the participants in these sectors to take up the challenge of ensuring efficient use of their resources to obtain value for money in terms of performance.

The total cost of construction in normal circumstances is expected to be the sum of the following costs:- Materials, Labour, site overheads, Equipment plant, Head office cost and profile but in many part of the world particularly in Nigeria, there are other cost to be allowed for.These costs according to Mbachu and Nkado (2004) have obvious negation implications for the key stake holders in particular and the industry in general. The fundamental factor for project success which forms the focus of this paper are (i) Budgeting and (ii) Budgetary control.

A budget is a management tool used in implementing the strategies adopted so as to realize declared objectives in respect to the mission or vision of the firm. It is essential in strategies corrective adjustments on clarification and determination of the subsequent direction of the firm (Hall, 2003).According to perks (2007), budgetary control is the use of budgets that relate the responsibilities of project managers to the requirements of the policy, and the continuous comparison of actual results with budgeted results to identify and implement specific actions to achieve the results intended, or to provide a basis for revising planned results. The use of budgetary control systems for planning purposes is part of a control mechanism, and provides a basis for financial planning (Perks, 2007). The use of budgetary controls by managers in the organization as an aid to decision making is essential towards achieving optimum performance of the firm (Meigs, 2000). Budgetary control is therefore a vital to enable attainment of organizational targets across the operations of the business. The future revenue and anticipated expenditure are usually reflected in the performance and position objectives of the organization. Therefore controls enable achievement of both short term and long term goals (Welsch and Gordon, 2000).According to Jones and Pendlebury (2000), the budget reflects the monetary values of the inputs allocated to each responsibility centre, 
and, where possible, shows the expected output or level of activity. For example, while some studies argued that budgetary control positively and significantly associated with performance (Lau and Tan, 1998), other studies have found either only a weak positive association between control and performance (Milani, 1975) or a negative association between two variables (Bryan and Locke, 1967).

The realization or achievement of construction project in the Nigeria construction industry, which is within the confine of cost and time factors has been the greatest task facing the clients, consultants and contractors. For efficient project delivery, proper cost management must be carried out and if not leads to failure in the delivery of construction project which manifests in the form of delay in project delivery and sometimes total abandonment of construction project. It is important to note that most of these abandonment and delay in project delivery are associated with inefficient budgeting, planning and control of cost in the pre-contract and post contract stages to construction. This paper therefore seek to address the issue of lack of proper cost management, individual budgetary control and provide solutions to enable efficient project delivery within the client cost ceiling.

\subsection{Literature Review}

In Nigeria like most developing countries, the construction industry plays a dominant role in the economic activities of the country. According to Olowo - Okere (1988), the construction industry accounts for about $60 \%$ of the Nation's capital investment and 30\% of the Grass Domestic Product (GDP). Furthermore, the construction industry is said to have combined about half of the total stock of fixed capital investment in the Nigeria economy (Olaloku, 1987). The industry also generates employment opportunities which place it second to the Government in the employment of labour (Husseini, 1991). When the construction industry was booming in the 1970's the country's economy experienced similar effects during that period. However, from early to mid 1980's the industry experience a jolt and its effect was felt in all spheres of national life (Isiadinso, 1988). Buhari (1991) reported that the lull in construction of early 80's was not limited to Nigeria alone.

However, the empirical research on informational impacts of budgetary controls has in general, produced consistent results. For example, Kren (1992), argued that budgetary control was associated with grater job-relevant information, which, in turn, was associated with higher job performance. Chong and Johnson (2002), argued that the act of control provides an opportunity for subordinates to gather, exchange, and disseminate job-relevant information to facilitate their decision-making process, which in turn improves job performance. This is in line with the present study.

In addition, Chong and Johnson (2007), suggested that the cognitive effect of control in goal-setting allows subordinates to gather, exchange and share job-relevant information. Chong and Johnson (2007) further suggested that the availability of job-relevant information allows subordinates to develop effective strategies or plans, which will help them to exert effort over time, in an attempt to attain their goals. Magner, Welker and Cmpbel (1996) found that control has a direct and positive effect on job relevant information. Also, Magner et al (1996) argued that the act of controls allows subordinates to interact with superiors whereby subordinates can ask questions to clarify goals, task strategies, conditions in the work environment and other issues that have an important impact on their jobs.On the other hand, Shields and Shields (1998) suggested that the cognitive impact of budgeting and budgetary controls improves a subordinate's quality of decisions as a result of sharing information with the superior.Budgetary control as proven management tool (Collier, 2006) helps organization management, and enhances improved performance of any economy in different ways. Its primary function is to serve as a guide in financial planning operators; it also establishes limits for departmental excesses. It helps project managers to make careful analysis of all existing operations, therby justifying expanding, eliminating or restricting present practice, (Musselman and Hughes 1981). Duncan (1996) highlighted some requirement for successful budgetary control system.

Atrill and McLaney, (2007) sees budget as a plan of dominant individuals in an organization expressed in monetary terms and subject to the constraints imposed by the participants and the environments, indicating how the available resources may be utilized, to achieve whatever the dominant individuals agreed to be the organization's priorities.

Hope and Frazer (2003), opined that the budget had grown beyond a financial tool. It is above all managerial tool; in essence, it is the best tool for making sure that key resources, especially performance resource are assigned to priorities and to results.

\subsection{Research Methodology}

Having identified the target group (Client, Consultants and Contractors) 70 respondents was purposively selected to include those who had handle project worth five million naira.. They were given structured, multiple choice and 
open ended questionnaire and 60 responses were received. Data from the questionnaire are presented in table while simple descriptive statistics is used to determine the strength of the information gathered, and tested by chi-square test statistic. The frequency tables comprises of actual and expected frequency. The test is conducted at $90 \%$ confidence limit and 0.05 level of significance. The following hypothesis will be tested:

\section{First Hypothesis}

$\mathrm{H}_{\mathrm{ol}}$ :Budgeting does not have any impact on the construction project delivery

$\mathrm{H}_{\mathrm{a} 1}$ :Budgeting has to an impact on the construction project delivery

Second Hypothesis

$\mathrm{H}_{\mathrm{o} 2}$ : Budgeting does not have any effect on the final cost of a project

$\mathrm{H}_{\mathrm{a} 2}$ : Budgeting has an effect on the final cost of a project

4.0 Result of Analysis

Table 4.1: An efficient budgeting at the pre-contact phase of the project can make the client achieve good value for his money

\begin{tabular}{lcc}
\hline Response & Frequency & Percentage $(\%)$ \\
\hline Yes & 41 & 63 \\
No & 2 & 3 \\
Other Reason & 17 & 34 \\
\hline Total & 60 & 100
\end{tabular}

Source: Field Survey,(2018)

From Table 4.1,63\% of respondents agreed that an efficient budgeting at the pre-contact phase of a project can make client achieve good value for his money.

Table 4.2: A proper and effective application of budgetary control in a project will lead to a drastic reduction in wastage of construction resources

\begin{tabular}{lcc}
\hline Response & Frequency & Percentage $(\%)$ \\
\hline Yes & 49 & 83 \\
No & 1 & 3 \\
Other Reason & 10 & 16 \\
\hline Total & 60 & 100 \\
\hline
\end{tabular}

Source: Field Survey, (2018)

From Table 4.2, the majority of the respondents (82\%) agreed that a proper and effective application of budgetary control in a project lead to a drastic reduction in wastage of construction resources.

Table 4.3: The practical application of budgeting and budgetary control is important for effective and efficient project delivery

\begin{tabular}{lcc}
\hline Response & Frequency & Percentage (\%) \\
\hline Yes & 55 & 92 \\
No & 0 & 0 \\
Other Reason & 5 & 8 \\
\hline Total & 60 & 100 \\
\hline
\end{tabular}

Source: Field Survey, (2018)

From Table 4.3, 92\% of the respondents agreed that the practical application of budgeting and budgetary control are important for effective and efficient project delivery

Table 4.4: Delays in project delivery most times, are as a result of inefficient budgeting and budgetary control

\begin{tabular}{lcc}
\hline Response & Frequency & Percentage (\%) \\
\hline Yes & 55 & 92 \\
No & 1 & 2 \\
Other Reason & 4 & 6 \\
\hline Total & 60 & 100
\end{tabular}


From table 4.4, 55 respondents, representing 92\% agreed that delay in project delivery most times occur as a result of inefficient budgeting and budgetary control

Table 4.5: The preparation of developer's budget before a project is embarked upon leads to efficient project delivery

\begin{tabular}{lcc} 
Response & Frequency & Percentage $\%$ \\
\hline Yes & 57 & 95 \\
No & 0 & 0 \\
Other Reason & 3 & 5 \\
\hline Total & 60 & 100 \\
\hline
\end{tabular}

Source: Field Survey, (2018)

From table 4.5, Majority of the respondents $(95 \%)$ agreed that the preparation of developer's budget before a project is embarked upon will lead to efficient project delivery.

Table 4.6: An efficient budgeting of cost/time has lead to major source of project abandonment in Nigeria today.

\begin{tabular}{lcc}
\hline Response & Frequency & Percentage (\%) \\
\hline Yes & 57 & 95 \\
No & 0 & 0 \\
Other Reason & 3 & 5 \\
\hline Total & 60 & 100 \\
\hline
\end{tabular}

Source: Field Survey, (2018)

From table 4.6, Out of low respondents surveyed 57 of them representing 95\% agreed that the inefficient budgeting of cost/time is a major source of project abandonment in Nigeria in recent times.

Table 4.7: An effective application of budgeting during the pre-contract stage and controlling at the post contract has positive effect on project delivery.

\begin{tabular}{lcc}
\hline Response & Frequency & Percentage (\%) \\
\hline Yes & 59 & 98 \\
No & 0 & 0 \\
Other Reason & 1 & 2 \\
\hline Total & 60 & 100 \\
\hline
\end{tabular}

Source: Field Survey (2018)

From table 4.7, Majority of the respondents (98\%) agreed that effective application of budgeting during the precontract stage has positive effect on project delivery.

Table 4.8: Variations and fluctuations in fluctuations in project result in an increased project cost, which may lead to delay or abandonment of the project.

\begin{tabular}{lcc}
\hline Response & Frequency & Percentage (\%) \\
\hline Yes & 54 & 90 \\
No & 2 & 3 \\
Other Reason & 4 & 7 \\
\hline Total & 60 & 100 \\
\hline
\end{tabular}

Source: Field survey (2018)

From table 4.8, 95\% of the respondents agreed that variation and fluctuation in project can result in an increased project cost, which may lead to delay or abandonment of the project.

Test of Hypothesis

Hypothesis 1:Budget does not have any impact on the construction project delivery.

The value of the table is 3.841 while that computed value is 6.86 . Therefore, reject the null hypothesis and accept the alternative which states that budgeting has an impact on the constitution project delivery.

Hypothesis II: Budgeting does not have any effect on the final cost of a project computation. 
Table value is 3.841 , while the computed value is 3.74 , therefore we reject the null hypothesis and accept the alternative hypothesis which states that budgeting has an effect on the final cost of a project. From the findings, we note that (i) effective budgeting and budgetary control on projects will result in reduction and elimination of project delay and abandonment usually pre dominant in the Nigerian construction industry by mapping out strategies for budget control, (ii) an efficient application of budgeting and budgetary control will lead to reduction in waste of construction industry, and, (iii) an efficient budget and budgetary control will help in reduction of unnecessary extension of time, which is rampant in most project today, by the preparation of programme of work schedule and following it up during the first contract stage.

\subsection{Conclusion}

Budgeting control techniques is used both at the design and construction phase and helps to manage the cashflow by controlling the number of variation and fluctuation effects on the project cost as well as monitoring contractor's claims and payments. A strict adherence to these factors will help to avert project delay, failure and abandonment and ensure efficient delivery of value for money to the client and the construction industry in general. Budgetary control cum management should therefore not end at design stage but all through the life cycle of the project.

The study reveals that abandonment or delay of projects from an inefficient control of cost. The study also strongly recommend, amongst many other that effective budgeting and budgetary control measure should be carried out both at the pre and post contract phase of the project

\section{References}

Anthony, R. and Govindarjan, V. (2003). Management Control Systems, Newyork: McGraw-Hill

Atrill, P. and McLaney, E. (2007). Management Accounting for Decision Makers, $5^{\text {th }}$ edition, Edinburgh: Pearson Education Limited, Prentice Hall

Bragg, S. (2007). Management Accounting Practices; A Guide for the Professional Accountant, New Jersey: John Wiley \& Sons, Inc.

Bryan, J. and Locke, E. (1967). Goal setting as a means of Increasing Motivation, Journal of Applied Psychology, June, 6 (4), 274-277.

Buhari, I.I (1991). Inflation and the Nigerian Economy. The Nigerian Quantity Surveyor. 1, 8-9

Chong, V. and Chong, K. (2002). Budget Goal Commitment and Information Effects of Budget Participation on Performance: a Structural Equation Modeling Approach, Behavoiural Research in Accounting, 2(4), 65-86

Chong, V. and Johnson, D. (2007). Testing a Model of the Antecedents and Consequences of Budgetary Participation on Job performance, Accounting and Business Research, 37(1), 3-19

Collier, P. (2006). Accounting for Managers; Interpreting Accounting Information for Decision-Making, $2^{\text {nd }}$ Edition, New Jersey: John Wiley \& Sons Ltd.

Glautier, M. and Under, B (1987). Cost Accounting, Financial Times, Prentice Hall

Hall, M. (2003). Information and Control of Decision Making, Retail Banking, Journal, 3

Hope, J. and Frazer, R. (2003). Beyond Budgeting, Harvard Business school press, Boston.

Huseini, A.A (1991). Construction and the National Economy. The Nigerian Quantity Surveyor, 4, 20-21

Isiadinso, E.I (1988). The Needs and Problems of the Building Industry in Nigeria, A Quantity Surveyors' View. Research Institution Seminar, Nigeria Building and Road Research Institute.

Jones, R. and Pendlebury, M. (2000). Public Sector Accounting, $5^{\text {th }}$ edition, Edinburgh: Pearson Education Limited, Prentice Hall, Financial Times

Kren, L. (1992). Budgetary Participation and Managerial Performance: The Impact of Information and Environmental Volatility, The Accounting Review, 67(3), 511-526. 
Lau, C. and Tan, J. (1998). The Impact of Budget Emphasis, Participation and Task Difficulty on Managerial Performance: A Cross-Cultural Study of the Financial Services Sector, Management Accounting Research, $9(2), 163-183 .$.

Magner, N., Welker, R. and Campbell, T. (1996). Testing a Model of Cognitive Budgetary Participation Processes in a Latent Variables Structural Equations Framework, Accounting and Business Research, 27(1), 41-50.

Mbachu, J.I.C and Nkado, R.N (2004). Reducing Building Construction Costs: The views of Consultants and Contractors. COBRA

Meighs, R. (2000). Information Analysis, $2^{\text {nd }}$ edition, London: Irwin Publishers.

Mendelson, S \& Greenfield H (1996) Taking Value Engineering into the Twenty- First Century. International Journal of Cost Estimation, Cost/Schedule Control and Project Management. 3 (7), 8

Milani, k. (1975) The Relationship Of Participation in Budget-Setting to Industrial Supervisor Performance and Attitudes: A Field study, The Accounting Review, 2, 274-285.

Musselman, V. \& Hughes, E. (1981) Introduction to Modern Business, New Jersey: Financial Times, Prentice Hall.

Olalokun I. A (1987) The Quantity Surveyor, The Second Tier Foreign Exchange Market and the Construction Industry in Nigeria: Options and challenges of construction in Nigeria. Journal of the Federation of Building and Civil Engineering Contactors in Nigeria 4 (1), 4-8

Olowo-Okere E.O (1988) Problems of Construction Management in Nigeria. Paper Presented to the Workshop on National Construction Policy, Badagry: ASCON

Perks, R. (2017) Financial Accounting; Understanding and Practice, $2^{\text {nd }}$ edition, Bershire: Mcgraw-Hill Education.

Shields, J. \& Shields, M. (1998) Antecedents of participative Budgeting, Accounting, Organizations and Society, $23(1), 49-76$.

Welsch. G, \& Gordon. P, (2000), Budgeting; Profit Planning and control, $5^{\text {th }}$ edition, Engleewood Cliffs: Prentice Hall College. 